\title{
KARL MARX E A TEORIA CRÍTICA: INFLEXÃO PARA A PRÁXIS DO CONHECIMENTO SOBRE MÍDIA E FORMAÇÃO
}

\author{
KARL MARX AND CRITICAL THEORY: A NECESSARY \\ INFLECTION FOR THE PRAXIS OF MEDIA \\ AND FORMATION KNOWLEDGE
}

\author{
KARL MARX Y LA TEORÍA CRÍTICA: INFLEXIÓN PARA \\ LA PRÁCTICA DEL CONOCIMIENTO SOBRE MEDIOS \\ DE COMUNICACIÓN Y FORMACIÓN.
}

Juliana de CAstro Chaves ${ }^{\mathrm{I}}$

\begin{abstract}
Resumo Esse artigo tem o objetivo de discutir algumas contribuições de Karl Marx, que também são fundantes para a Teoria Crítica, no sentido de refletir a respeito da importância da práxis na produção do conhecimento sobre mídia e formação. Para fazer este debate, retomamos e priorizamos tanto as contribuições de Marx em seu diálogo com a filosofia e os economistas, economia política clássica, no que diz respeito ao método que revela e transforma a realidade, como o debate que Horkheimer realiza com os fundamentos de Marx para diferenciar a Teoria Crítica da Teoria Tradicional e alertar o quanto a produção de determinado conhecimento pode reproduzir uma sociedade desigual. Revelar as contradições, a relação entre todo e parte, superar o imediato, o aparente, para decifrar as determinações do real e abordar a produção social de qualquer objeto pesquisado, é fundamental para o conhecimento crítico. Problematizar a produção em meio ao primado da representação nos estudos sobre mídia e formação faz um giro que demarca a diferenciação dos estudos críticos e de uma práxis necessária à atualidade.
\end{abstract}

Palavras-chave: Karl Marx; Teoria Crítica; Práxis; Mídia; Formação.

Abstract This article aims to discuss some contributions of Karl Marx, which are also foundations for Critical Theory, in order to reflect on the importance of praxis in the production of knowledge about media and formation. In order to make this debate, we retake

Universidade Federal de Goiás (UFG), Goiás/GO - Brasil. 
and prioritize both Marx's contributions in his dialogue with philosophy and economists, classical political economy, regarding the method that reveals and transforms reality, such as Horkheimer's debate with the foundations of Marx to differentiate the Critical Theory from Traditional Theory, and to warn how much the production of a certain knowledge can reproduce an unequal society. Revealing the contradictions, the relation between all and part, overcoming the immediate, the apparent, deciphering the determinations of the real and approaching the social production of any object searched is fundamental to critical knowledge. To problematize production in the midst of the primacy of representation in the studies on media and formation makes a turning that demarcates the differentiation of critical studies and of praxis necessary to nowadays.

Keywords: Karl Marx; Critical Theory; Praxis; Media and Formation.

Resumen Ese artículo tiene el objetivo de discutir algunas contribuciones de Karl Marx, que no dejan de ser fundamentales para la Teoría Crítica, en el sentido de reflexionar sobre la importancia de la práctica en la producción del conocimiento sobre medios de comunicación y formación. Para abrir a ese debate, retomamos y priorizamos tanto las contribuciones de Marx en su diálogo con la filosofía y los economistas, economía política clásica, en lo que dice respecto al método que revela y transforma la realidad, como el debate que Horkheimer realiza con los fundamentos de Marx para diferenciar la Teoría Crítica de la Teoría Tradicional y alertarnos cuanto la producción de un determinado conocimiento puede reproducir una sociedad desigual. Revelar las contradicciones, la relación entre todo y parte de ello, superar lo inmediato, lo aparente, para descifrar las determinaciones de lo real y abordar la producción social de cualquier objeto investigado, es fundamental para el conocimiento crítico. Problematizar la producción en medio a la regla de la representación en los estudios sobre medios de comunicación y formación hace un giro que acota la diferenciación de los estudios críticos y de una práctica necesaria a la actualidad.

Palabras-clave: Karl Marx; Teoría Crítica; Práctica; Medios de Comunicación; ForMACIÓN.

\section{Elementos fundantes em Karl MARX Para uma teoria Crítica}

Um negro é um negro. Apenas dentro de determinadas condições ele se torna um escravo. Uma máquina de fiar algodão é uma máquina de fiar algodão. Ela se transforma em capital apenas em condições determinadas. Fora dessas condições, ela tampouco é capital como o ouro é por si próprio moeda ou o açúcar é o preço do açúcar (MARX, 2003, p. 69).

Por que envergamos a vara para a importância de Karl Marx para uma teoria crítica? São vários os argumentos. Inicialmente, acreditamos que, embora esse autor seja base da Teoria Crítica da Sociedade, principalmente dos teóricos da primeira geração, muitas vezes as discussões que alguns leitores frankfurtianos estabelecem com os fundamentos de Marx são reproduzidas sem entendimento, o que deixa reduzido o diálogo que a Teoria Crítica da Sociedade efetivou com esse autor. 
Além do mais, Marx se apresenta atual, já que revelou as contradições da sociedade do capital, que, com continuidades e descontinuidades, hoje se encontra mais do que fortalecida de forma hegemônica e monopolista. A atualidade de Marx está embasada no fato de que os processos que determinam a sociedade continuam, ou seja, ainda permanecem as estruturas determinantes. Isso significa que a teoria marxista não é atual por ela mesma, mas justamente por ser arguida constantemente e indicar elementos da compreensão da realidade (RESENDE, 2016).

Adorno (1986, p. 63) ressalta, em defesa de Marx, que a crítica ao capitalismo não é obsoleta, mesmo que "as relações de produção se revelaram [tenham se revelado] mais elásticas do que Marx imaginava". Apesar da contradição de classes ter perdido a relevância para alguns, persiste a metamorfose do trabalho em mercadoria, além de a sociedade ser produzida e reproduzida a partir da sociedade de classes. Com todas as reestruturações do capital, é o sistema de produção capitalista que produz não só a sociedade, mas as relações, o indivíduo e a vida. Devido à sociedade se apresentar com contradições, Adorno (1986, p. 63) defende que a discussão do capitalismo tardio precisa ser "desenvolvida teoricamente e não só através da apresentação dos fatos que, por sua vez, é claro, contribuem de muitos modos para a crítica, mas que, segundo a Teoria Crítica, também encobrem a estrutura".

Outra contribuição de Marx no sentido de delinear uma teoria crítica é que ela se faça práxis social. Tentar revelar os mecanismos ocultos, os nexos, as mediações de determinada realidade, a produção e a reprodução da sociedade, é não confirmar o estado atual, é superar, é ser crítico. Revelar a ilusão é postular a sua transformação, é combater. Por isso, é práxis social. Ao se revelar o funcionamento da sociedade, revela-se a ilusão necessária para a sua manutenção. Marx, ao refletir acerca do mundo burguês, tem forte vinculação histórica. Sua teoria nasce da práxis e se pretende ser práxis. A teoria de Marx é uma teoria da História que pretende intervir na história. Ela é vinculada duplamente à práxis histórica na sua origem e na sua destinação (RESENDE, 2016). Essa vinculação é do âmbito da ética.

Para desvelar essa sociedade, Marx (2003) nos alerta que o histórico não pode ser tomado como natural, pois isso fixa a História como foi e deverá ser. Fixa o presente na sua manutenção, o que é essencial para o funcionamento e a perpetuação da sociedade, tal qual se apresenta. Requer-se, então, que o dado como ele se apresenta corresponda apenas ao movimento inicial de apreensão. Reafirmando a importância da História, em resposta a Proudhon, Marx (1985, p. 212) ressalta que as categorias econômicas não são ideias eternas, preexistentes, mas "expressões teóricas de relações históricas de produção, correspondentes a um determinado nível de desenvolvimento da produção material".

Os homens não são apenas um resultado da história em sua indumentária e apresentação, em sua figura e seu modo de sentir, mas também a maneira como veem e ouvem é inseparável do processo de vida social tal como este se desenvolveu através dos séculos. Os fatos que os sentidos fornecem são pré-formados de modo duplo: pelo caráter histórico do objeto percebido e pelo caráter histórico do órgão perceptivo. Nem um nem outro são meramente naturais, mas enformados pela atividade humana, sendo que o indivíduo se autopercebe, no momento da percepção como perceptivo e passivo (HORKHEIMER, 1983, p. 125). 
Até no que se acha mais natural, a produção material surpreende, mostrando a sua determinação.

O capital levou séculos, antes de surgir a indústria moderna, para prolongar a jornada de trabalho até seu limite máximo normal e, ultrapassando-o, até o limite do dia natural de 12 horas. A partir do nascimento da indústria moderna, no último terço do século XVIII, essa tendência transformou-se num processo que se desencadeou desmensurado e violento como uma avalanche. Todas as fronteiras estabelecidas pela moral e pela natureza, pela idade ou pelo sexo, pelo dia e pela noite foram destruídas. As próprias ideias de dia e de noite, rusticamente simples nos velhos estatutos, desvaneceram-se tanto que um juiz inglês, em 1860, teve de empregar uma argúcia verdadeiramente talmúdica para definir juridicamente o que é dia e o que é noite. Eram as suas orgias do capital (MARX, 2003, p. 320).

Ao estudar abissalmente a sociedade capitalista, Marx (2003) revelou as determinações que medeiam a constituição das classes sociais.

Não pintei a cor-de-rosa as figuras do capitalista e do proprietário fundiário. Mas aqui só se trata de pessoas na medida em que elas são a personificação de categorias econômicas, suportes de determinados interesses e relações de classes. O meu ponto de vista, segundo o qual o desenvolvimento da formação econômica da sociedade é assimilável à marcha da natureza e à sua história, pode menos que qualquer outro tornar o indivíduo responsável por relações de que socialmente ele é afinal a criatura, por mais que ele se queira libertar delas (p. 18).

Revelar essas determinações auxilia a compreensão da forma que o sujeito assumiu na sociedade burguesa, a forma do indivíduo (RESENDE, 2007). Marx oferece bases para o entendimento da articulação entre indivíduo e sociedade capitalista, a subjetividade e os mecanismos de alienação, fetiche e reificação que se acirram na sociedade contemporânea devido à presença de suas determinações.

Nesse sentido, a teoria crítica

não tem a função de um indivíduo isolado nem a de uma generalidade de indivíduos. Ao contrário, ele considera conscientemente como sujeito a um indivíduo determinado em seus relacionamentos efetivos com outros indivíduos e grupos, em seu confronto com uma classe determinada, e, por último, mediado por esse entrelaçamento, em vinculação com o todo social e a natureza. Este sujeito não é pois um ponto, como o eu da filosofia burguesa; sua exposição (Darstellung) consiste na construção do presente histórico (HORKHEIMER, 1983, p. 132).

Mas essas mediações que constituem a sociedade e o indivíduo não estão claramente visíveis. Elas se ocultam na produção. Enfatizar a questão da produção e não a da representação não é uma querela teórica, nem um a priori, mas tem uma implicação política, 
de práxis social. Marx (1978, p. 103), logo ao início de seu texto Introdução à Economia Política, esclarece-nos de que produção estamos falando: "a produção material. Indivíduos produzindo em sociedade, portanto, a produção dos indivíduos determinada socialmente". O modo produtivo implica a produção de relações sociais, a formação de determinado sujeito e produtos. O modo de produção não produz só coisas, mas produz vida.

A atualidade de Karl Marx no que diz respeito aos vários pontos levantados aqui se mostra ainda mais essencial nas investigações a respeito da relação entre mídia e formação, após as constatações da pesquisa de Morais (2016). Morais (2016), em seu Estado do Conhecimento sobre as Mídias no GT de Educação e Comunicação da ANPED, entre 2004 e 2013, compreendeu o conhecimento elaborado sobre as mídias no Brasil durante 10 anos. Dessa pesquisa, duas questões justificam o realce da importância dos estudos críticos levarem em conta a contribuição de Marx na análise da relação entre mídia e formação.

Morais (2016), ao analisar os temas abordados nos trabalhos que debatiam mídia, encontrou que a ênfase ao sentido, à significação, à linguagem, à subjetivação, às narrativas, às práticas discursivas e ao discurso ou outras derivações predominava na maioria deles. Essa importância era tanta que chegava a competir com o objeto estudado, confundia-se com a temática, o que dificultou o levantamento do foco do tema do trabalho. Ou, então, o "sentido" e suas "derivações", que são do âmbito da representação do objeto, podiam ser considerados o próprio tema/objeto. A autora chega a propor que se inserisse antes de cada tema (infância, juventude, televisão, jornal, TICs, internet, EAD, cinema, cibercultura, jogo eletrônico, corpo etc.) a expressão "produção de sentido de" ou o "discurso sobre" ou "narrativas sobre" a grande maioria dos trabalhos podiam ser catalogados. Isso significa que a grande maioria dos trabalhos, resguardadas as diferenças epistemológicas, podia ser catalogada em um único tema: "práticas discursivas".

Isso indica que existe uma tendência do GT de investigar a representação em qualquer temática ou objeto, ou seja, em qualquer mídia ou produto midiático. Esse primado do discurso é tão marcante que se apresenta também na justificativa do marco epistemológico/teórico escolhido. Ou seja, mesmo que existam denominações de referenciais teóricos diferentes (Estudos Culturais, Análise do Discurso, Dialógica, Sócio-História e Sociocultura etc.), a grande maioria se justifica por abordar algo que é do âmbito do discurso, da representação, do sentido, da percepção, do olhar, da recepção, da interação dialógica, da linguagem, da intersubjetividade, da subjetividade, isto é, enfatiza a questão de como o indivíduo, seja a criança, o jovem, o professor, educador, leitor, consumidor, espectador, representa a mídia, apresentando uma ênfase subjetivista, geralmente descolada das mediações objetivas (MORAIS, 2016).

Uma segunda tendência que Morais (2016) destaca é que os estudos que relacionam mídia e formação, também em sua grande maioria, positivam a mídia em seu referencial teórico, ou seja, partem do a priori de que as mídias carregam um em si que propicia mais ensino-aprendizagem, riqueza de sentidos, subjetividade, interatividade, diálogo, conhecimento e autonomia, e, na execução, na efetivação, no empírico, a mídia também se realiza dessa forma ou, quando não exerce a sua natureza, responsabiliza as questões individu- 
ais, micro, grupais, particulares, que devem ser aprimoradas por meio de treinamentos, políticas públicas ou por aquisição de equipamentos. Em outras palavras, a atribuição da determinação pelas mídias não estarem exercendo o seu papel é local, micro, sem relação com a totalidade, com o macro. Só em menor quantidade estão os trabalhos que tensionam a relação entre mídia e formação, revelando contradições tanto no marco teórico como na realidade, trabalhos que não partem de um a priori sobre mídia (MORAIS, 2016).

Mas o que essas duas tendências vêm a nos revelar acerca da importância de se resgatar Karl Marx e, mais especificamente, "a produção" no debate sobre mídia? Podemos ressaltar algumas questões fundamentais que se inter-relacionam em Marx, não só nas elaborações teóricas, mas na práxis. Esse autor nos alerta o quanto é perigoso realizar a identidade entre representação e objeto. "A representação plena volatiliza-se na determinação abstrata” (MARX, 1978, p. 116-117).

Para a consciência - e a consciência filosófica é determinada de tal modo que para ela o pensamento que concebe é o homem real, e o mundo concebido é, como tal, o único mundo real. Para a consciência, pois, o movimento das categorias aparece como o verdadeiro ato de produção - que apenas recebe um impulso do exterior - cujo resultado é o mundo, e isso é exato porque (aqui temos de novo uma tautologia) na medida em que a totalidade concreta, como totalidade de pensamento, é, na realidade, um produto do pensar, do conceber; não é de nenhum modo o produto do conceito que se engendra a si mesmo e que concebe separadamente e acima da intuição e da representação, mas é elaboração da intuição e da representação em conceitos (MARX, 1978, p. 117).

Marx nos alerta que, se a realidade, na sociedade capitalista, não é captada em suas mediações na forma em que se apresenta para o sujeito, essa opacidade se produz na forma de consciência do sujeito, produz-se como ilusão.

Assim é que Hegel chegou à ilusão de conceber o real como resultado do pensamento que se absorve em si, procede de si, move-se por si; enquanto o método que consiste em elevar-se do abstrato ao concreto não é senão a maneira de proceder do pensamento para se apropriar do concreto, para reproduzi-lo mentalmente como coisa concreta. Porém, isso não é, de nenhum modo, o processo da gênese do próprio concreto (MARX, 1978, p. 117).

O concreto não é visível a olho nu. Não há correspondência empírica imediata no concreto. Portanto, é necessário sair da abstração que é a ideia pela ideia e realizar a inversão do modelo hegeliano.

Meu método dialético, por seu fundamento, difere do método hegeliano, sendo a ele inteiramente oposto. Para Hegel, o processo do pensamento - que ele transforma em sujeito autônomo sob o nome de ideia - é o criador do real, e o real é apenas sua manifestação externa. Para mim, ao contrário, o ideal não é mais do que o material transposto para a cabeça do ser humano e por ela interpretado (MARX, 2003, p. 28). 
Marx nos alerta para o quanto certos conhecimentos que se afirmam científicos podem ser ideologia. A ideologia se configura como um conjunto de ideias anteriores, ideias que se afirmam pela ideia, pautadas na abstração, que seguem uma lei natural tratada como imutável (MARX, 2002). Para o autor, é necessário seguir o "método cientificamente exato" para sair da aparência.

\begin{abstract}
Não se trata aqui do grande desenvolvimento mais ou menos completo dos antagonismos sociais, que resultam das leis naturais da produção capitalista. Trata-se sim destas leis em si mesmas, de tendências que se manifestam e realizam com uma necessidade de ferro. O país industrialmente mais desenvolvido não faz mais que mostrar aos que o seguem na escala industrial a imagem do seu próprio futuro. [...] Perseu cobria-se com uma nuvem para perseguir os monstros; nós mergulhamos completamente na nuvem, até aos olhos e às orelhas, para podermos negar a existência de monstruosidades. (MARX, 1978, p. 116-7).
\end{abstract}

A construção do conhecimento pode partir dos aspectos abstratos, do simples, da captação imediata da realidade, do manifesto (elementos representacionais), mas é fundamental revelar as mediações concretas de uma realidade, os nexos internos, o complexo. A captação como se apresenta é real, mas é falsa (RESENDE, 2016). Nesse sentido, é fundamental interrogar sobre a aparência da realidade, mesmo que ela seja dada como clara, conhecida e verdadeira.

Ao contrário da filosofia alemã, que desce do céu para a terra, aqui é da terra que se sobe ao céu. Em outras palavras, não partimos do que os homens dizem, imaginam e representam, tampouco do que eles são nas palavras, no pensamento, na imaginação e na representação dos outros, para depois chegar aos homens em carne e osso; partimos dos homens em sua atividade real, é a partir do seu processo de vida real que representamos o desenvolvimento dos reflexos e das repercussões ideológicas deste processo vital. E mesmo as fantasmagorias existentes do cérebro humano são sublimações resultantes necessariamente do processo da sua vida material, que podemos constatar empiricamente e que repousa em bases materiais. Assim, a moral, a religião, a metafísica e todo o restante da ideologia, bem como as formas de consciência a elas correspondentes, perdem logo toda a aparência de autonomia. Não têm história, não têm desenvolvimento; ao contrário, são homens que, desenvolvendo sua produção material e as suas relações materiais, transformam, com a realidade que lhes é própria, seu pensamento e também os produtos do seu pensamento. Não é a consciência que determina a vida, mas sim a vida que determina a consciência. Na primeira forma de considerar as coisas, partimos da consciência como sendo o indivíduo vivo, e na segunda, que corresponde à vida real, partimos dos próprios indivíduos reais e vivos, e consideramos a consciência unicamente como sua consciência (MARX, 2002, p. 19).

Nesse sentido, é a realidade que vai conceber a ideia, que só assim será totalidade concreta, síntese material de determinações (MARX, 1978). É fundamental buscar a síntese das determinações do real. A síntese é o concreto pensado, que reúne forças e antiforças, e 
não a apreensão e o registro de uma sequência de aparências. O processo de síntese aparece no pensamento como resultado, por isso não é idealista.

O concreto é concreto, porque é a síntese de muitas determinações, isto é, unidade do diverso. Por isso, o concreto aparece no pensamento como o processo da síntese, como resultado, não como ponto de partida, embora seja o verdadeiro ponto de partida e, portanto, o ponto de partida também da intuição e da representação (MARX, 1978, p.116-117).

Nesse processo, é o objeto que vai indicar quais mediações são importantes. A ordem das determinações é a realidade que vai apontar, ou seja, ela está submetida à práxis histórica. Um elemento determinante em um período pode não o ser no outro e determinadas determinações podem estar subsumidas a outras (MARX, 1978).

Seria, pois, impraticável e errôneo colocar as categorias econômicas na ordem segundo a qual tiveram historicamente uma ação determinante. A ordem em que se sucedem se acha determinada, ao contrário, pela relação que têm umas com as outras na sociedade burguesa moderna, e que é precisamente o inverso do que parece ser uma relação natural ou do que corresponde à série da evolução histórica. Não se trata do lugar que as relações econômicas ocupam historicamente na sucessão das diferentes formas da sociedade. Menos ainda de sua série "na ideia" (PROUDHON), que não passa de uma representação falaciosa do movimento histórico. Trata-se de sua conexão orgânica no interior da sociedade burguesa moderna (MARX, 1978, p. 122).

Conhecer tudo não é conhecer o todo e, por isso, precisamos nos debruçar sobre o objeto para revelar o que é mais determinante em sua constituição (RESENDE, 2016). Marx afirma a importância da realidade para a construção da ideia como totalidade concreta, como síntese material de determinações. Ele alerta que há uma espécie particular de produção social que é historicamente produzida.

Quando se trata, pois, de produção, trata-se da produção em um grau determinado do desenvolvimento social, da produção de indivíduos sociais. Por isso, poderia parecer que, ao falar da produção, seria preciso ou seguir o processo de desenvolvimento em suas diferentes fases, ou declarar desde o primeiro momento que se trata de uma determinada época histórica, da produção burguesa moderna (MARX, 1978, p. 104).

A História possui uma essencialidade transitória (RESENDE, 2016): ela dura enquanto duram as determinações. "A relação essencial da teoria com o tempo histórico não se baseia na correspondência de partes isoladas da construção teórica com o período histórico" (HORKHEIMER, 1983, p. 148).

Outro elemento importante é que 
A teoria não tem hoje um conteúdo e amanhã outro. As suas alterações não exigem que ela se transforme em uma concepção totalmente nova enquanto não mudar o período histórico. A consciência da teoria crítica se baseia no fato de que, apesar das mudanças da sociedade, permanece a sua estrutura econômica fundamental - a relação de classe na sua figura mais simples - e com isso a ideia da supressão da sociedade permanece idêntica. Os traços decisivos do seu conteúdo, condicionados por este fato, não sofrem alterações antes da transformação histórica. Por outro lado, a história não ficará estagnada até que ocorra esta transformação. O desenvolvimento histórico das posições, com as quais o pensamento crítico está atrelado, altera a importância dos conhecimentos científicos especializados para a teoria e a práxis críticas (HORKHEIMER, 1983, p. 149).

Parte-se do presente mediado e não do presente tal e qual se apresenta. Para Marx (1978, p. 120),

\begin{abstract}
A anatomia do homem é a chave da anatomia do macaco. O que nas espécies animais inferiores indica uma forma superior não pode, ao contrário, ser compreendida senão quando se conhece a forma superior. A economia burguesa fornece a chave da economia antiga etc. Porém, não conforme o método dos economistas, que fazem desaparecer todas as diferenças históricas e veem a forma burguesa em todas as formas de sociedade.
\end{abstract}

Não é toda história do objeto que tem que ser resgatada, mas a história que não passou. É o momento pretérito que se atualiza (RESENDE, 2016). Para desvelar o objeto, é essencial estar aberto à contradição, mas essa não é empiricamente observada e imediata. Marx revelou a contradição entre o capital e o trabalho, revelou a mercadoria. $\mathrm{O}$ que aparece no mercado ao se perguntar sobre a mercadoria é que há uma troca, uma relação justa e de diálogo, que a mercadoria possui valor de uso. Marx (2003) partiu desse conhecido, revelou que o valor de uso é real, mas é falso, pois, mesmo sendo o que aparece, a mercadoria é também valor de troca, fetiche e é valor. Nesse sentido, a mercadoria é e não é valor de uso e essa contradição não está na teoria, mas na produção da mercadoria, o que reverbera na sua manifestação, como também no sujeito que a compra, que com ela se relaciona e a representa.

Consideramos que levar em conta a aparência no sentido de revelar as determinações concretas de uma realidade, a historicidade de um objeto, a relação da parte com o todo com suas contradições é fundamental para se pensar uma teoria crítica para a análise da produção do conhecimento sobre mídia e formação.

\title{
UM PENSAR CRÍTICO SOBRE A RELAÇÃo ENTRE MÍDIA E FORMAÇÃo
}

O pensamento, a formulação da teoria, seria uma coisa, enquanto que o seu objeto, o proletário, seria outra. Contudo, a função da teoria crítica torna-se clara se o teórico e a sua atividade específica são considerados em unidade dinâmica com a classe dominada, de tal modo que a exposição das contradições sociais não seja meramente uma expressão da situação histórica concreta, mas também um fator que estimula e que transforma (HORKHEIMER, 1983, p. 136). 
A discussão desenvolvida no tópico citado aponta que devemos estar atentos para a produção e não só para a distribuição, a circulação, o consumo, a recepção, "olhar" ou "ver" os produtos culturais e a mídia em si, ou seja, temos de ter cautela para não ficarmos apenas no como o indivíduo se relaciona com a mídia, como a mídia é concebida pelo indivíduo e como um e outro indivíduo se relacionam a partir da mídia, perdendo a materialidade do objeto. "Na realidade social, a atividade de representação jamais se manteve restrita a si mesma, pelo contrário, sempre atuou como um momento dependente do processo do trabalho que tem, por sua vez, uma tendência própria" (HORKHEIMER, 1983, p. 133). Temos que perseguir o objeto (mídia) no sentido de revelar as suas mediações. É fundamental discutir sobre a produção do objeto e sobre a produção do sujeito realizada pela mediação do objeto, que se relaciona com o objeto em determinadas condições históricas.

Ao enfatizarmos a importância da produção no estudo sobre as mídias e suas contradições, indicamos a cautela que se deve ter com a tendência predominante de se investigar um sujeito ou uma mídia que se faz sem história, sem sociedade, sem totalidade. O resultado de um estudo dessa procedência é um sujeito que se relaciona com uma mídia ou com algum produto midiático e que também se apresenta sem história. Um sujeito que é analisado descolado da totalidade da sociedade, em que o particular se dilui no singular, perdendo o universal, desembocando em um reducionismo subjetivista (RESENDE, 2007). Com esse viés, é possível estabelecer uma positividade a priori para a relação do sujeito com a mídia ou da própria mídia, postura com que devemos ter cuidado.

Claro, também temos que ter cuidado com a história sem sujeito, em que o sujeito é um mero reprodutor da realidade, um receptor passivo, um manipulado. Essa perspectiva se delineia, como afirma Resende (2007), como um reducionismo objetivista. Tributárias dessa perspectiva encontram-se as posturas imediatamente negativistas sobre as mídias, a ideia rígida de que a indústria cultural manipula totalmente o sujeito, como se não tivesse nada no sujeito que aderisse, pedisse determinados produtos. Ou então que a história já acabou, que não existem contradições, mecanismos de fuga ou resistência do sujeito diante da sociedade administrada.

É importante debater a mídia e os produtos da indústria cultural a partir da produção. Quando defendemos isso, ressaltamos que a produção não produz, unicamente, o objeto do consumo, mas também o modo de consumo, ou seja, produz objetiva e subjetivamente. A produção cria, pois, os consumidores". [...] De modo que a produção não somente produz um objeto para o sujeito, mas também um sujeito para o objeto" (MARX, p. 1978, 109). Como afirma Marx: "A fome é fome, mas a fome que se satisfaz com carne cozida, que se come por meio de uma faca ou de um garfo, é uma fome muito distinta da que devora carne crua com ajuda das mãos, unhas e dentes" (p. 110). Isso implica não perder, na análise da relação sujeito-objeto, a produção concreta dos produtos culturais, a sua feição, em não pensá-los apenas na subjetividade do sujeito, como também perceber que a subjetividade do sujeito é mediada socialmente por objetos.

No que diz respeito a esse ponto, tratamos com cautela vertentes que, na análise de certas produções midiáticas, pautam-se em ideias inerentemente subjetivas, que represen- 
tam robinsonadas do produtor ou do receptor, descoladas das condições concretas da sociedade. Se a produção está dentro dos ditames da racionalidade do capital e prolonga as formas de vida organizadas segundo o regime do lucro, não revelar isso é perpetuar a sociedade necessária para a continuidade do sistema de dominação (ADORNO,1986). O capital cria e reproduz, na sociedade, as condições reais, a base material para a sua produção (MAAR, 2001, pp. 102-103). Nesse sentido, analisar apenas a recepção e o sentido apartados da produção é retirar as determinações concretas do sujeito e do próprio produto analisado e, por conseguinte, dificultar as possibilidades de transformação.

Ao mesmo tempo, a análise da produção é que vai auxiliar o entendimento da natureza da mídia e não um a priori qualquer. Segundo Horkheimer (1983, p. 128), "a classificação de fatos em sistemas conceituais já prontos e a revisão destes através da simplificação ou eliminação de contradições" eliminam a práxis. "As categorias: melhor, útil, conveniente, produtivo, valioso, tais como são aceitas nesta ordem [social], são para ele suspeitas e não são de forma alguma premissas extra-científicas que dispensam a sua atenção crítica" (HORKHIMER 1983, p. 130).

Um elemento que nos ajuda a pensar no enaltecimento do sujeito e na imediata valoração positiva da mídia, ou seja, que ela é capaz de produzir em si mesma riqueza de subjetividade, riqueza de sentidos de sujeitos em interatividade, está na ideologia do indivíduo autônomo, livre, bandeira necessária à sociedade burguesa. A ideia de liberdade atrelada à autonomia, em que o trabalhador é livre para vender a sua força de trabalho no mercado, é sustentáculo dessa sociedade. No entanto, basta fazer a pergunta que Marx fez para revelar essa falácia. O trabalhador é livre para vender pelo preço que quiser e para quem quiser a sua força de trabalho? O trabalhador pode vender a sua força para outro trabalhador? Não, só alguns têm condições de comprar. Portanto, esses sujeitos não são livres, autônomos no mercado. Não existe uma relação de igualdade. Assim, não é uma relação de diferença entre os que compram e os que vendem a força de trabalho que está em jogo, que está na base da realidade, mas, sim, a desigualdade. Então, devemos desconfiar dessa autonomia de pensamento, dessa riqueza de subjetividade que se multiplica pela mídia.

A experiência com o objeto (mídia), que podia ser uma possibilidade de o sujeito resgatar as contradições da mídia, também se encontra mutilada na atualidade e cada vez mais subsumida na informação pontual, desconectada, intercambiável e efêmera, que será modificada no próximo instante por outra informação. Segundo Benjamin (1983), a informação visa comunicar o puro em si do acontecimento sem que a pessoa que informa imprima nela a sua marca e possa transmiti-la como experiência. A informação é relacionada à vida prática e tem a sua base na verificabilidade. Nesse processo, há a nomeação das coisas, algo que se parece com a "fala dos viajantes que, no trem, dão nomes a todos os lugares pelos quais passam como um raio" (ADORNO, 1996, p. 405).

Parceiros dessa "riqueza" empobrecida de informações, os produtos midiáticos são apresentados sem um quadro de referência que lhes dê sentido, espelhando certa identidade entre senso comum, informação e conhecimento, em que cada cena deve resultar, o quanto possível, da situação imediatamente anterior e não da ideia do todo, em que os conteúdos 
são apresentados como neutros, como se aparentemente não tivessem relação com a história, com conceitos ou estudos e pesquisas (CHAVES, 2015).

É esse indivíduo pseudoautônomo que é chamado a emitir opinião na indústria cultural. E esse dizer é considerado pela mídia como sinônimo de debate, de socialização de ideias, de riqueza de entendimento, de exercício de democracia plena. Associada a essa lógica, temos o fetiche da linguagem, que desprega do falar humano as determinações concretas do sujeito falante. Somos especialistas em generalidades e todos estão autorizados a falar sobre qualquer assunto.

Ancorada na defesa automática da riqueza dos indivíduos, temos a defesa da riqueza das relações. A ampliação das relações virtuais e da interatividade é considerada imediatamente sinônima de riqueza de contato, de diálogo e de pensamento autônomo. Pautada no que se considera conquista, temos a defesa das mídias balizada no fato de ela mediar a diversidade da linguagem, a democratização da informação e a possibilidade do alcance e da ampliação dos processos educacionais e, por que não dizer, da formação.

No entanto, a crença de que várias pessoas conversando, trocando opiniões é necessariamente riqueza de ideias, democracia, tomada de decisão justa é um engodo. Como emblema, basta acompanhar o processo do Golpe de 2016, denominado impeachment da presidenta Dilma Rousseff, que seguiu rigorosamente os trâmites formais de debate e de escuta de lados opostos para ver que forma e conteúdo não se encontraram. Já havia acordos preestabelecidos, veredito tomado.

No âmbito cinematográfico, vemos em Dogville (2003), dirigido por Lars von Trier, outro caso também emblemático. A personagem Grace, interpretada por Nicole Kidman, é impingida a sacrifícios e julgada pela comunidade no pátio da igreja sob a justificativa de uma pseudojustiça, quando o que estava em jogo eram necessidades físicas, hedonistas, os próprios interesses dos habitantes da vila, levando todos à barbárie.

O pensamento burguês é constituído de tal maneira que, ao voltar ao seu próprio sujeito, reconhece com necessidade lógica o ego que se julga autônomo. Segundo a sua essência, ele é abstrato, e seu princípio é a individualidade que, isolada dos acontecimentos, se eleva à condição de causa primeira do mundo ou se considera o próprio mundo (HORKHEIMER, 1983, p. 132).

É necessário problematizar o que entendemos por relação, já que, no que diz respeito às relações, é curioso percebermos, como afirma Marx (1978, p.104), que é nessa sociedade burguesa, em que as condições sociais alcançaram o mais alto grau de desenvolvimento, que cada vez mais se produz o indivíduo isolado, o indivíduo individualista, que não reconhece o social como constitutivo de sua humanidade. Isso implica que estar em relação não significa reconhecer o outro como parte constitutiva de seu ser. Ao mesmo tempo, o indivíduo, ao falar, se julga a expressão de uma coletividade. "O nós retórico é empregado a sério. $\mathrm{O}$ falar se julga o instrumento de todos. Na sociedade dilacerada do presente, este pensamento é, sobretudo em questões sociais, harmonicista e ilusionista" (HORKHEIMER, 1983, p. 132). 
A soeiedade eapitalista, pautada em uma razão instrumentale pragmátiea, eonstitui uma soeiedade que é apenas meio para o sujeito (HORKHEIMER, 1983). Como Marx (2003) reitera, as diferentes formas de relaȩões soeiais se erguem diante do indivíduo eomo um simples meio para seus fins privados, como uma neeessidade exterior, e essa situaȩão é preoeupante, já que o não reeonheeimento do soeialem nós faz que o indivíduo interiorize esse social de forma passiva, reproduza-o, aereditando fortemente que as ideias são frutos de suas elaboraęões.

Parceiras dessa ideia se encontram a aversão à busca da verdade e a defesa intransigente de narrativas sobre a realidade. Nesse sentido, a verdade é reservada à interpretação dos indivíduos sobre a realidade, aos insides, o que não deixa de embasar certo cinismo contra toda verdade e todo pensamento. Podemos ver isso na mídia, mais uma vez, no denominado processo de impeachment da presidenta Dilma em 2016. A grande mídia enfatizou narrativas. Narrativas de políticos e de partidos, como se no processo não houvesse uma materialidade, não houvesse bases reais concretas que o sustentassem. Se chegamos ao exagero do argumento, podemos indicar que esse pensamento é tributário do fim das metanarrativas, da teoria e da história, não do sujeito, mas da sociedade que constitui esse sujeito.

Atualmente, buscar a verdade se relaciona apenas a um ranço com o passado, com o dogmatismo, o autoritarismo, a perpetuação do pensamento hegemônico, a história dos dominadores. Nesse sentido, não existe mais verdade, mas posicionamentos sobre uma realidade. Essa postura oferece base para um relativismo absoluto, que se inscreve como democrático, mas que também se revela autoritário. Podemos ver bem onde isso está nos levando. A proposta da "Escola sem Partido" para a educação no Brasil é a tentativa de retirar a verdade da história ou a história da verdade. "A teoria crítica não está nem "enraizada como propaganda totalitária nem é "livre-flutuante" como a intelligentista liberal" (HORKHEMER, 1983, p. 141). Naturalizar essas questões nos torna inertes diante do real. Saber que o produzido é historicamente situado é base da transformação. Revelar isso atualiza embates.

O sentido não deve ser buscado na reprodução da sociedade atual, mas na sua
transformação. Por isso para o modo de julgar dominante a teoria crítica apare-
ce como subjetiva e especulativa, parcial e inútil, embora ela não proceda nem
arbitrariamente nem ao acaso. Como ela contraria o modo de pensar existen-
te que permite a continuidade do passado favorecendo os interesses da ordem
ultrapassada, e se opõe aos garantes de um mundo partidário, a teoria crítica
aparenta ser partidária e injusta (HORKHEIMER, 1983, p. 138).

É fundamental esclarecer que a contradição das mídias e de seus produtos, no que diz respeito à formação, está na realidade, é advinda dessa sociedade, mesmo que possa ser ocultada. Ela não é só epistemológica/teórica, mas é histórica e real. Isso significa que a contradição não pode ser resolvida teoricamente. Nessa sociedade, a contradição não se resolve, ela só se desenvolve (RESENDE, 2016). É isso que faz o movimento da história. Uma teoria tem de revelar esse movimento. Ela deve se fazer na história e deve ser desafiada pela história. Portanto, o olhar que traz um a priori reduz ou culpabiliza pequenos grupos, indivíduos, sem revelar as determinações sociais, pode terminar reforçando reformas ou resoluções parciais que ocultam as verdadeiras determinações, reproduzindo a lógica da sociedade. 
A reflexão dos estudos sobre mídia em sua análise do particular não pode perder a totalidade. A parte (mídia) e a totalidade (sociedade capitalista) estão intrinsecamente relacionadas. Essa relação não é uma relação de mútua influência, de interdependência, mas de determinação. É numa determinada produção social que os sujeitos são constituídos e que a mídia é produzida. Desse modo, resolver situações de mídia pontualmente pelo micro, descolando-as das questões do todo da sociedade, é ingênuo. A tentativa de trazer uma resolução para questões que nem foram analisadas em sua complexidade importa um procedimento de razão que se destina a ser prático. É a conversão da razão em desrazão. Por isso Marx (2003) não presume, a priori, uma saída, uma solução para a questão social, mas elabora a ciência a partir do conhecimento crítico do movimento histórico, um movimento que produz as condições materiais da emancipação.

"A teoria como momento de uma práxis que conduz a novas formas sociais não é uma roda dentada de uma engrenagem em movimento" (HORKHEIMER, 1983, p. 136). Isso quer dizer que soluções não devem ser apressadas, embora haja desaprovações do senso comum ou a necessidade de urgência na resolução dos problemas. O que se observa no processo de teste da eficiência é o consumo de uma teoria, mesmo quando ela é elaborada separadamente de sua aplicação. Ao mesmo tempo, a aplicação parcial da teoria crítica a processos fragmentados e repetitivos, a exclusão da classe social das elaborações marxistas e a junção de elementos da teoria crítica com o pensamento tradicional atendem a fins progressistas, que não correspondem à verdade da teoria crítica. Retirar a contradição das classes sociais, retirar o debate sobre a sociedade capitalista onde qualquer objeto é produzido, é retirar o macaco do filme King Kong (RESENDE, 2016).

Analisar a mídia sem perder a totalidade significa perceber que essa sociedade é produzida nos moldes capitalistas. Nesse sentido, a educação não tem sido necessariamente formação, pois ela tem se voltado para a funcionalidade social, que cobra o pragmatismo, a preparação para o mercado de trabalho. Por isso, é necessário perguntar pelo conteúdo ético do processo formativo em função de sua determinação social. Para pensar em formação, Adorno mostrou o quanto é essencial fazer a pergunta sobre que educação queremos? Perguntar o que desacostumamos de perguntar. Fazer essa pergunta significa assumir que a educação tem uma orientação. É para a continuidade dessa sociedade? Não, é para revelar essa sociedade, evitar a barbárie, evitar o primado da dominação.

Em tempos de hegemonia de determinada mídia, cabe a nós revelar as contradições. O movimento de contestação não está em querer retornar a um estado anterior nem proibir o acesso aos veículos de comunicação, mas buscar desenvolver as mediações, desvelar as contradições e formar sujeitos capazes de realizar a análise crítica dos mecanismos de sua formação. Aí está a força da teoria crítica, da práxis transformadora.

O pensamento crítico é motivado pela tentativa de superar realmente a tensão, de eliminar a oposição entre a consciência dos objetivos, espontaneidade e racionalidade, inerentes ao indivíduo, de um lado, e as relações do processo de trabalho, básicas para a sociedade, de um outro (HORKHEIMER, 1983, 132). 
Tentar sair da tendência que desvia a produção objetiva do conformismo é o papel do teórico crítico. "A teoria que impulsiona a transformação do todo social tem como consequência a intensificação da luta com a qual está vinculada" (HORKHEIMER, 1983, p. 138). Para Horkheimer (1983), não existe teoria da sociedade que não inclua interesses políticos. Mesmo que ela se autonomeie neutra, terá que se decidir ao agir e pensar na atividade histórica concreta. Não dá para realizar um trabalho intelectual para depois decidir entre metas e caminhos revolucionários, liberais ou fascistas. Não existe separação entre sujeito cognoscente e sujeito atuante.

\section{REFERÊNCIAS}

ADORNO, Theodor W. Capitalismo tardio ou sociedade industrial. In: COHN, Gabriel (Org.). Theodor W. Adorno: grandes cientistas sociais. São Paulo: Ática, 1986. p. 62-75.

BENJAMIN, Walter. Sobre alguns temas em Baudelaire. In: BENJAMIN, Walter; HORKHEIMER, M.; ADORNO, T. W. ; HABERMAS, J. Textos escolhidos. $2^{\mathrm{a}}$ ed. São Paulo: Abril Cultural, 1983. (Os Pensadores).

. Teoria da semicultura. Educação \& Sociedade, Campinas-SP, ano 17, n. 56, p. 388-411, dez. 1996. (Original publicado em 1959).

. Educação \& emancipação. Tradução Wolfgang Leo Maar. São Paulo: Paz e Terra, 2003.

CHAVES, Juliana de C. Capitalismo dos monopólios e indústria cultural: formação do sujeito sujeitado. In: CHAVES, Juliana de C.; BITTAR, Mona; GEBRIM, Virginia S. Escritos de Psicologia, Educação e Cultura. Campinas: Mercado das Letras, 2015. p. 63-96.

TRIER, Lars von; WINDELOV, Vibeke. Dogville. [Filme-vídeo]. Produção Vibek Windelov. Direção Lars von Trier. França, Itália, Dinamarca, Noruega, Suécia, Finlândia, Holanda: Zentropa Entertainments, 2003. 2h59 min.

Descrição do tipo. som.

HORKHEIMER, Max. Teoria Tradicional e Teoria Crítica. In: BENJAMIN, Walter. HORKHEIMER, Max.; ADORNO, Theodor. W. ; HABERMAS, Jurgen. Textos escolhidos. $2^{\mathrm{a}}$ ed. São Paulo: Abril Cultural, 1983. (Os pensadores).

MAAR, Wolfgang Leo. Da subjetividade deformada à semiformação como sujeito. Psicologia \& Sociedade, São Paulo, v. 13, n. 2, p. 92-141, jul./dez. 2001.

MARX, Karl. A Miséria da Filosofia. São Paulo: Global, 1985.

. Para a crítica da economia política. São Paulo: Abril Cultural Ltda. (Os

pensadores). 1978 p. 103-125. 
O Capital, crítica da economia política. Rio de Janeiro: Civilização Brasileira, 2003. v. 1 . e ENGELS, Friedrich. Ideologia alemã. São Paulo: Martins Fontes, 2002.

MORAIS, Tatyane P. de Moraes. Mídia e educação: um estudo sobre as mídias no GT de Educação e Comunicação da ANPED entre 2004 e 2013. 2014. Dissertação (Mestrado em Pós-graduação em Educação - Mestrado e Doutorado). Universidade Federal de Goiás.

RESENDE, Anita C. O passado que não passa: a atualidade da contribuição do método em Marx para a formação de professores. Educativa, Goiânia, v. 19, n. 1, p. 1001-1019, set./ dez. 2016.

. Da relação indivíduo sociedade. Educativa, Goiânia, v. 10, n. 1, p. 29-45, jan.jun. 2007.

\section{Dados da Autora}

Juliana de Castro Chaves

Doutora em Psicologia Social pela Pontifícia Universidade Católica de São Paulo. Professora do Programa de Pós-Graduação em Educação e do curso de Psicologia da Faculdade de Educação da Universidade Federal de Goiás. Goiás/GO - Brasil. julichcastro@gmail.com

Submetido em: 30-03-2017

Aceito em: 22-05-2017 